Milan Kovacevic ${ }^{1}$

University Novi Sad, Faculty of Economics

Nebojsa Pavlovic ${ }^{2}$

University Kragujevac,

Faculty of Hotel Management and Tourism
SCIENTIFIC REVIEW ARTICLE doi:10.5937/ekonomika1604095K

Received: September 30, 2016

Accepted: November 16, 2016

\title{
GLOBALIZATION AND THE KNOWLEDGE SOCIETY
}

\begin{abstract}
Globalization is a multi-layered, long-running and irreversible process, which includes intensive changes, deterritorialization and acceleration of social activities. One vitally important aspect of globalization concerns its impact on the knowledge society. Through Americanization of universities and the Bologna Process, globalization has commercialized higher education, turning knowledge into a type of commodity. Under the influence of market forces, the university is starting to lose its long-guarded autonomy, becoming just another subject of corporative capitalism. Homogenization, standardization, specialization, economies of scale, marketing concepts, consumerism, as well as the primacy of knowledge that contributes to economic growth and higher profits are some of the key factors that directly affect higher education systems and institutions throughout the world. The goal of this study is to determine whether globalization is altering the essence of higher education-and how. In conclusion, we may state that future research ought to be increasingly aimed at examining the chances and threats of globalization in the context of the knowledge society.
\end{abstract}

Keywords: globalization, the knowledge society, the Bologna Process

JEL Classification: A14, F20, F60

\section{ГЛОБАЛИЗАЦИЈА И ДРУШТВО ЗНАЫА}

\begin{abstract}
Апстракт
Глобализачија је вишеслојан, дуготрајан и незаустављив процес, који обухвата интензивне промене, детериторијализацију и убрзавање друштвених делатности. Један од најзначајнијих аспеката глобализачије тиче се юеног утицаја на друштво знања. Преко американизаџије универизета и Болоњског прочеса, глобализачија је комериијализовала високо образовање, знање претварајући у робу. Под утицајем тржишних сила, универзитет почиње да губи свој дуго чувани карактер аутономности, постајући тек још један од субјеката корпоративног капитализма. Хомогенизација, стандардизација, специјализација, економија обима, маркетинг кониепти, конзумеризам, те примат знања која доприносе економском развоју и повећању профита неки
\end{abstract}

\footnotetext{
${ }^{1}$ milkov87@gmail.com

22racapn@gmail.com,
} 
су од кључних чинилаца који непосредно делују на системе и институције високог образована широм планете. Циљ ове студије јесте да утврди да ли глобализација меға суштину високог образовања - и како. Долази се до закључка да наредна истраживања треба све више усмеравати ка испитивању шанси и претьи глобализације у контексту друштва знања.

\section{Кључне речи: глобализащија, друштво знања, болоњски процес}

\section{Introduction}

In recent years, the term Globalization has begun to be widely used. Numerous researches on this topic are published on a daily basis. Despite this fact, there is no precise definition of the aforementioned term. This is mostly a consequence of the complexity of the term, which is difficult to define. In addition, it is a result of the vividness of the issue, which doesn't adhere to a theoretical framework. In academic parlance, the term globalization has been incorporated with the aim of emphasizing that the world has entered a new epoch at the end of the $20^{\text {th }}$ century; the period is marked by intensive changes, deterritorialization, and acceleration of social activities. The post modern world (Bauman, 2000), the late modern world (Giddens, 1991) or the second modernity (Beck, 1992) cannot be considered separately from globalization, which can be conceived as a process which creates a widespread network of economic, technological, political and cultural interchange, where the rise of similar models on the wider social basis becomes a characteristic of modern times.

The number of attempts to highlight the complexity of interwoven parts in defining globalization is booming. Even though the scope of globalization is wide, there is a dimension of this process which is superior to others. It falls under the economic dimension; it is related to the universalization of capitalism, as well as to the open market as an unstoppable force, to whose needs every aspect of social life subdues. Indeed, there is no structure of consciousness which is saved from the influence of the all-pervasive logic of the market, not even higher education. By transforming universities into enterprises, by making them inferior to the law of supply and demand, the economic dimension of globalization has a decisive impact on academic institutions. Since the 1980s, the market has become a dominant force, enslaving the university, while the society and the state are playing supporting roles. The investigation of the relation between globalization and higher education, therefore, requires a thorough analysis of these phenomena.

Does globalization change the essence of higher education? Does the market invade the autonomy of educational systems and institutions? Is there place on the university for values which are not expressed in money? Does globalization incorporate consumerism into the field of education? Are we witnessing the development of the economy of highly educated or fachidiots? Should objectives of the humanistic view of education take second place to the economy and job market? This paper tries to provide answers to some of these questions. 


\section{The roots of change - the global economy and the knowledge society}

During the second half of the 20th century, and especially during the 1970s, drastic changes occurred in the global economy. According to Fredric Jameson, it was about a third great original expansion of capitalism around the globe which followed after the earlier expansions of the national market and the imperialist system (Jašović, 2005). Industrial capitalism, also known as Fordism, was replaced with Postfordism. Impressive growth of trade and competition, surges in capital flow, progress in information technology, development of flexible manufacturing systems, the need for constant increase and expansion of market, the rise of international marketing, as well as the reinforcement of the role of multinational corporations and financial conglomerates, are some of the crucial changes in the system of global economy. Through privatization and deregulation, the adoption of neoliberal policies has resulted in general decrease in public spending and social security. By establishing a widespread neoliberal capitalist system, the growth-share matrix is expanding to those areas of social activity which have not previously been the center of its attention. (Liessmann, 2009; Hromadžić, 2008).

Various authors have differently named these rapid and long-term socio-economic changes. In literature, we come across terms about cognitive capitalism; post-industrial society, neoliberal society, the information society, entrepreneurial society, postcapitalist society, risk society, and even about boring society. However, in accordance with the widespread belief according to which the knowledge is the foundation of competitiveness in the global economy, a term "the knowledge society" has become commonly accepted. This term derives from Peter Drucker. The fact that the knowledge has become the most important resource, and not just a resource, is what makes our society post-capitalist, Drucker points out. The modern market economy is a business world in which individuals and organizations can survive only if they possess certain kind of knowledge and skills. Primarily, it is about the knowledge of instrumental character. It can be understood as means to accomplishing social and economic results. It is tangible, practical, useful knowledge. According to Drucker, what we now perceive as knowledge should by all means be highly specialized. The knowledge workers work in the knowledge society, whereby the results are not accomplished by individuals, but by organizations. According to Drucker, the knowledge worker must possess knowledge at an advanced level of expertise and be prepared to live in a global and tribalized world. (Avramovic, 2008).

Consequently, with the development of global economy, higher education has obtained a new strategic role as a central resource of competitiveness, a measure of capacity for attracting and retaining highly qualified workforce and investments. The university acquires a vital role in economic growth, as well as the role of indirect source of profit for corporations. Established by the listed beliefs, the domination of neoliberal doctrine has encouraged authors to think about the role of higher education through productivity measures. Corporate university has been established on the basis of neoliberal ideology and the knowledge society. Knowledge is perceived as goods; a product which is offered and its value depends on the needs and demands of the market. 


\section{The preponderance of economies - the United States and the Bologna Process}

When it comes to commercialization and performance on the market, American universities have been ahead of European ones for decades. In the modern commercial practice of American universities, its existence is not new, but its enormous scope. Commercialization in the true sense of the word was limited to the sphere of the university life. However, since 1975, universities have become more aggressive in their attempt to profit from their research or educational activities. Many institutions have set up programs for patent licensing, profitable educational endeavors over the Internet and wide range of other commercial activities (Bock, 2005). Although commercialization emerged due to a myriad of reasons, none of them would have been successful if there hadn't been a chance to make more money; a chance which was ensured by technologically sophisticated economy based on knowledge. Namely, universities have become the main source of factors which represent the basis of constant growth and progress - highly specialized professionals with specialist knowledge and achievements in the field of science, which others could use to produce new products, treatments or medicine (Pavlovic, 2013). The sudden increase in possibilities to exchange education, expert advice and scientific knowledge for exorbitant sums of money, has resulted in the fact that the commercialization prevails in American universities (Bok, 2005).

While educational institutions in the USA were left to their own devices since their foundation, and thus as such developed an entrepreneurial approach - academic culture in Europe was quite different. After all, the idea of university is a European creation. The idea of university, whose origin can be traced back to educational institutions in Ancient Greece, experienced its last fundamental changes at the beginning of the 19th century, when, under the influence of Wilhelm von Humboldt, the medieval university underwent a major transformation. Humboldtian model of higher education, often called the ideal model, has had a significant impact in the past two centuries, becoming an integral part of the global educational system. However, since the end of the 20th century, the perception of the development of higher education in Europe has significantly changed. After it was established in World War II, a strong connection between university and state was shaken and then broken. Since it depended on the existence of a stable welfare state, this kind of coexistence implied that university, as an independent science, was to be supported and largely financed by public body. The increasing intensity of competition in global market, gradual weakening of the role of the state, falling behind regarding efficiency and flexibility of USA universities and the need for young workforce in order to maintain competitiveness, in the meantime has imposed the need for reviewing and redefining the role of institutions in higher education. Encouraged by the newly developed situation, European countries united and adopted the Bologna declaration in June of 1999, which imposes the basic principles of reform of universities. Among other things, the declaration demands that the countries coordinate their education policies, create a unique "European Higher Education Area", adopt a system of easily readable and comparable degrees and a system based on two main cycles.

Economic changes had an impact on the position of universities and had a considerable influence on the change of objectives of the higher education. The process of extinction of the welfare state, i.e. its transformation into administrative-bureaucratic 
agents of the neoliberal market, with the purpose of maintaining economic competitiveness of the European Union in a race against Japan and the USA, consequently leads to the transformation of all social aspects, including higher education (Hromadzic, 2007). In Europe, the Bologna process has significantly changed the character of European university by distancing it from a traditional academic culture and adopting the American model of higher education. General market-oriented economy, the establishment of a system of credits (ECTS) as a standard unit which enhances employability and mobility, shorter period spent at the university, and ISO certified diplomas, can be considered as an Americanization of European universities. This can be interpreted in many ways, but the fact is that with the adoption of the Bologna declaration, European countries have for the first time influenced the organization and the content of universities. This is against the basic principle of how the university should function - autonomously. The forsaken autonomy of university includes economic dimension - independency over rules of capitalist market in the social structure. Thus, higher education becomes a subject of corporate capitalism.

\section{Global(ized) studying and teaching - the virtual university}

The most dramatic improvement in the area of non-traditional education has certainly been the spread of distance learning with the help of the Internet. By describing university campus and buildings in it as "highly unsuitable and totally useless", Peter Drucker predicted that university, as an institution in which a person spends a certain amount of time, will not withstand (Bok, 2005). These kinds of long-term predictions are not a novelty; they were always following the development of new technologies during the entire 20th century. However, the real impact of these findings, according to the rule, was significantly minimal than its proponents had expected.

Be that as it may, the technology did expand the range of possibilities for learning. The Internet truly has characteristics which make it an attractive teaching tool. Primarily, this medium is interactive; it allows easy updates of teaching material, and the development of adapted curriculums. The Internet enables teaching to be available all around the world. Through teleconference, students can have a discussion with participants from all over the globe. Distance learning also offers significant educational opportunities for people who are not able to physically attend the university. Besides these characteristics, the Internet is not an effective replacement for traditional university education. A lot of things that are crucial for the students' development originate from the experiences which one cannot get online. For instance, communication with others. And because of this, it is believed that the virtual community cannot replace the real one. Furthermore, it can be said that the concept of distance learning changes the role of the educator, teacher and professor in the educational process. Unlike the traditional way of teaching, the Internet courses are not designed by one person; they demand the entire team of people: course designers, writers, technicians, instructors, and others (Bok, 2005). When the teaching staff and courses are transferred to the Internet, administration gains total control, which allows room for monitoring, organizing, discipline and even censure.

The potential market of distance learning seems to have no boundaries. The possibilities of the Internet have spread beyond the USA, creating a global space for 
virtual education. A large number of potential students from countries which do not have respected universities, are now a part of the universities in the USA, Great Britain, Australia and other developed countries. Even little-known institutions offer online courses for students from all over the world. For universities, this is a convenient way to decrease costs of teaching, while simultaneously increasing the number of students. The University of Phoenix, which was established as a for-profit college of vocational education, has managed to enroll 110.000 students until 2001, and many of them pursue their studies online (Bok, 2005).

Foreign students are very important for a lot of universities. The need to "export" higher education in this way is motivated by the fact that it is profitable. The aim is to create a market in order to offer a wide range of educational services. The recipe for earning money from this kind of education is to gather a large audience. In addition, the expenses should not be enormous. In other words, it would be good to use likable teachers, add attractive visual tools, but to avoid providing a lot of feedbacks and keep interaction at a minimum. According to this, these courses would not use the full potential of technology. However, the one thing that technology provides is the development of interactive lectures, which use stimulations, games and other things that stimulate discussion. But, this is the most expensive kind of distance learning, the one that costs as much as the traditional lectures. In that way, it can be observed that technology is used to make profit rather than enhance the quality of and access to the higher education.

\section{Market relations and profit, the McDonaldization of Higher Education}

The tendency to perceive education as a private good is increasing the competitive spirit among different sectors and institutions of higher education. This is achieved by promising certain incentives and rewards. Thereby, the competition is not a problem. On the contrary, it is desirable. However, the problem is that the competion is initiated by the profit. While trying to make a profit, universities aspire to reduce expenditure and increase revenue, which inevitably changes the essence of education and jeopardizes some basic academic values.

The need for money is a chronic condition of the corporate university. Under the influence of the market, a trend of decreasing the public participation in the financing higher education has developed, despite the increased number of students. Universities, including state ones, are forced to find new sources of funds - tuition fees, donations, and, especially, research revenues. The burden of financing higher education is falling on the individuals, thus eliminating those who cannot afford expensive tuition fees. Since donation requires a return of favor, the influence of those donating is getting greater, thus changing the form of the institution. The massification of higher education reduces the quality of education students are receiving, making it inferior to the quantity and economies of scale, which can be seen when an unprofitable course is cancelled. Courses which are not able to attract an abundance of students and fill classrooms, and in that way use economies of scale, are simply removed from the curriculum.

Scientific research activities stress the relation between universities and corporations. That relation of multinational companies and academic institutions is symbiotic, and those 
companies can invest their resources in researches. The knowledge, which was previously free and available to everyone, is now confidential and aimed at the market. Nowadays, universities make contracts with different enterprises; they even open their own enterprises, designed for commercial exploitation of discoveries (Srećković, 2008). It is true that this leads to important scientific results and also to the reallocation of funds to researches at the expense of teaching. Also, a certain gap has been created between commercial and non-commercial disciplines. Lastly, ethical problems are appearing because of the conflict of interest, which has emerged from the relationship between the company which finances research and those researchers who are conducting it. However, universities can carry out research only if it is profitable. This creates winners and losers, and highlights the differences between the smaller number of those research institutions which are successful and a greater number of those universities which are mediocre (Jung, 2003). The 'race' to make a profit turns into a battle for survival.

The expansion represents one of the most important trends in higher education. Before World War II, 5\% of people living in Western Europe and the USA were enrolled at a university. Now, the student population has grown to $30 \%$ in Western Europe, and $50 \%$ in the USA. According to UNESCO, there were about 138 millions of students in 2005. 21 million of which were studying in China, 20 million in the EU, 18 million in the USA, and 11 million in India (Dolenc, 2007). These statistics are the best indicators of the transition of universities from elite to mass institutions. University's connection with the market has resulted in the fact that it is not on the top of the ivory tower anymore. Globalization inevitably changes the university, transforming it into a sort of Mc University - a widely available, standardized service.

Education has definitely become a product. The tendency towards standardization of knowledge, which is reflected through increasingly present engineering component, which strives to develop methods and algorithms that will make curriculum equal at every level, can be spotted in the products of multinational companies. However, the process of determining ingredients of hamburger or making a refreshing drink has its explanation - the ability to achieve economies of scope through increased efficiency leads to success and global domination. When it comes to academic institutions, things are not that simple. Within the context of higher education, the fear of homogenization can be expressed through imperialism, the need to impose Western values, and diminish cultural specificities. When it comes to colonization, it should be considered as a market colonization, rather than American. (Milosevic, 2006).

No matter how efficient it might be, without appropriate propaganda, manufacturing process will not lead to success. Although the reality is completely different, McDonald's, Coca-Cola, and other similar companies, will convince the consumer that their products taste nice, and that they will feel better if they spend money on them. Truly, it seems that education is achieving the same result - a well-packed, promoted product, but it is in its essence extremely empty and mostly hazardous. The reality tells us that universities, perceiving their future students as consumers, are in an identical way humoring their expectations by using well-known marketing concepts. Seduction is also manifested in educational context, which leads to a brand new and scary form of consumerism. The essence takes second place, students are happy with a brand; the act of shopping is much more important than the purchased product. We can only guess all the devastating results this logic, with its dehumanizing consequences, could bring. 
The principles of corporate capitalism are prevailing in the universities today. An academic institution is treated as an enterprise which produces knowledge and sells curriculum and scientific services to the free market. Accordingly, it is believed that university, no matter if it is private or public, should be managed according to the principles of economic management, that its performance should be measured by the profit rate, and that rectors and deans should be considered as managers. The university is becoming a factory, its main task being to produce a certain number of specialists, train them and direct them to perform assignments.

Education is increasingly viewed in terms of economics terminology. It will gradually stop being a part of social policy, and become a part of political economy. Numerous studies, which are dealing with this problem, mostly investigate the connection between investment in education and the percentage of economic growth. Nowadays, education is explained quantitatively through calculation of profit which brings investment in human resources; by connecting it to finances, development of human resources, efficiency, effectiveness, economies, and revenues and expenses. The perception of higher education as an investment in the human resources has become an integral part of educational policies all around the world, and especially in developing countries. This kind of narrow and instrumentalist view cannot be perceived as an achievement in the area of education. It is the product of mechanistic perception of the world, where people are viewed as tools and shaped in order to successfully fulfill different functions in economic machinery of the society. Beside practical usefulness, education and learning are concerned with the nature and essence of man, society and its structure. They contribute to the growth and development of personality, and are aimed at its spiritual and intellectual part, rather than just at tangible. Hence, education is good and valuable (Savicevic, 2007). Instead of talking about human resources, it is more useful to speak about human potential - about a man with all of his abilities and creative capabilities.

It is clear that the aforementioned tendencies in science education policy are aimed at the existence of that knowledge which doesn't bring any profit and which isn't productive. Measured by criteria of economic rationalism, the knowledge which is not applicable on the market is considered useless. Adjusting the university to the demands of the market has blurred, if not even excluded from its program, the knowledge which humanistic social science brings forth. They have been replaced by techniques characteristic for the management of corporations and business systems (Risman, 2010). The exams are even designed in the similar manner, with scales, points and charts, dumbing down and rationalization of the curricula, which instead of rewarding talented individuals who possess critical thinking skills, reward those who think in terms of surviving.

\section{Conclusion}

It is hard to predict how universities are going to escape from the grip of the increased hyperspecialization, to which there is no end in sight and which is responsible for the phenomenon of students and professors who possess extremely narrow views of the world. All fields, of course, have their scope and they encourage students to 
choose some professions, but that should not be done on behalf of creating a devastating Fachidiotismus and abandonment of intellectual freedom. Therefore, the classroom is at the risk of becoming a morose, expressionless place which apart from offering and licensing has little to give. Before, professors gave lectures; nowadays, they are mostly professionals, entrepreneurs and careerist, just like in the business world. Intellectuals who come out from those conditions are only experts who do not possess an understanding of moral and social demands of their calling.

In these kinds of conditions, the term which refers to the general or universal education is questionable. Even the term education, which is related to the formation of a mature person and to the process of becoming a versatile being - could be abandoned in favor of training, teaching and practicing.

The process of differentiating knowledge is ambivalent, since it contains a narrow view of the reality as a whole, and an attempt to broaden the knowledge of its parts. Therefore, it is about an increased knowledge which tries to focus on the little things. However, if we dare to take a step back in order to view the image from a distance, instead of looking at it up close, we will notice that similar difficulties are present on a global level. It is has to do with insight and perspective. Namely, it is a paradox, which can be reflected in the growth of the processes of globalization on one hand and fragmentation of knowledge on the other hand.

With this in mind, one simple question remains unanswered: How can the partly educated people solve global problems? Indeed, due to the lack of thorough consideration of reality, the intellectual conformism, which was created by technisistic type of thinking which destroys diversity, has a difficult time in dealing with the praxis, even though it strives for it.

\section{References}

Beck, U. (1992). Risk Society.Towards a New Modernity, New Delfhi, Sage

Bauman, Z. (2000). Dialectic of Modernity, London.Sage.

Dolenec, D. (2007). Društveno odgovorno sveučilište: A što Bolonja ima s tim?, Političko obrazovanje, 3 (3-4).

Giddens, A. (1991). The Consequences of Modernity, Stanford University Press.

Liessmann, K. P. (2009). Teorija neobrazovanosti - zablude društva znanja, Jesenski i Turk, Zagreb

Rizman, R. (2010). Akademski kapitalizem, Mladina. From:http://www.mladina.si/ tednik/201034/akademski_kapitalizem. Retrived 6.September 2016

Yang, R. (2003). Globalisation and Higher Education Development: A Critical Analysis, International Review of Education, 49(3-4).

Аврамовић, 3. (2008). Да ли је друштво знања нови тип друштва, Социолошки преглед, 42(1).

Бок, Д. (2005). Универзитет на тржишту, Клио, Београд.

Јашовић, Б. (2005). Дехуманизација и самоотуђење између потрошачке културе и глобалних ризика постмодерног доба, Социологија, 47(2). 
Милошевић, Б. (2006). Интердисциплинарност и филозофски идеал јединства наука, Архе, 3(5-6).

Павловић, Н. (2013). Криза у друштву знања, Кључне компетенције у образовању одраслих, Зборник радова, Андрагошко друштво ХАД, Загреб

Савићевић, Д. (2007). Социо-филозофски основи Болоњске декларације, Педагошка стварност, 53(7-8).

Срећковић, М. (2008). Универзитет у ери тржишта, Магазин Балкан, број 5, стр 14.

Хромаџић, Х. (2007). Болоњски кою. From: http://www.h-alter.org / vijesti/ bolonjski-konj-1-dio. Retrived 6.September 2016

Хромаџић, Х. (2008). Друштво знања - о чему је заправо ријеч. From: http:// www.h-alter.org/vijesti/drustvo-znanja-o-cemu-je-zapravo-rijec-prvi-dio. Retrived 6.September 2016 